\title{
The inflammatory reaction during chronic venous disease of lower limbs
}

\author{
Dominika Ojdana $^{1 *}$, Kamil Safiejko ${ }^{2 *}$, Alina Lipska ${ }^{3}$, Pawel Sacha1, \\ Piotr Wieczorek $^{1}$, Piotr Radziwon ${ }^{3}$, Jacek Dadan ${ }^{2}$, Elżbieta Tryniszewska ${ }^{1}$
}

\author{
${ }^{1}$ Department of Microbiological Diagnostics, ${ }^{2} \mathrm{Ist}^{\mathrm{st}}$ Department of General and Endocrinological Surgery \\ Medical University of Białystok, Białystok, Poland \\ ${ }^{3}$ Regional Centre for Transfusion Medicine in Białystok, Białystok, Poland
}

\begin{abstract}
Chronic venous disease (CVD) is an insufficiency of distal veins caused by their partial or total obstruction, endothelial distension and functional disorders. Chronic venous disease of lower limbs is common problem and affects millions of people. In this article we suggest that inflammatory process is involved in the structural remodeling in venous valves and in the venous wall, leading to valvular incompetence and the development of varicose veins.
\end{abstract}

Key words: chronic venous disease, inflammatory process, leukocytes

\section{Introduction}

Chronic venous disease (CVD) is an insufficiency of peripheral veins caused by their partial or total obstruction, endothelial distension and functional disorders. Chronic venous disease is one of the most common diseases [1]. It is a significant social, medical and economic problem [2]. CVD of lower limbs is frequent among Western populations [3,4].

Manifestations of chronic venous disorders of lower limbs include: teleangiectases, varicose veins, edema, trophic changes and chronic leg ulceration. More advanced abnormalities of vasculature system such as: edema, skin changes and ulcerations are called chronic venous insufficiency (CVI) [5].

Implementation of the international classification system (CEAP) (the clinical class $-\mathrm{C}$, the ethiology $-\mathrm{E}$, the anatomical $-\mathrm{A}$, the pathophysiology $-\mathrm{P}$ ), created by American Venous Forum, describes occurrence and intensity of venous pathology, and it is a significant progress of chronic venous disorders characterization $[5,6]$. Thanks to the international CEAP classification the identification and treatment of CDV is easier.

Correspondence: E. Tryniszewska, Dept. of Microbiological Diagnostics, Medical University of Bialystok, J. Waszyngtona Str. 15A, 15-269 Bialystok, Poland; tel./fax: (+4885) 7468571, e-mail: zdmik@umwb.edu.pl
Despite numerous research about the pathophysiology of CVD the underlying etiology remains not well understood. The aim of this study is to present new views about the CVD pathophysiology. In this article we try to present the inflammatory process as the major cause of CVD.

\section{Pathophysiology}

The reason of the majority of chronic venous disease symptoms is prolonged exposure to venous hypertension caused by venous wall abnormalities and valvular incompetence [7].

The venous hypertension and outflow disorders may be caused by process which leads to pathological changes of the venous wall. Development of venous hypertension is caused by reflux through incompetent venous valves [8]. Reflux of blood can be present in deep veins of lower limbs, superficial veins of lower limbs and perforator veins of lower limbs. Venous reflux is one of the major mechanism responsible for development of venous hypertension [9]. A lot of research about the etiology of venous valves incompetence have been done. One of them assume, that the venous wall extension is the reason of valvu-

*both authors have equal contribution 
lar incompetence [10]. Susceptibility of the venous wall for stretching mainly depends on the smooth muscles and connective tissue fibres content in tunica media. It's known that intracellular matrix alterations of the venous wall is the cause of the development of CVD [11-13]. The property qualitative and quantitative composition of the intracellular matrix is the condition of the correctly building and integrality of the venous wall. Collagen and elastin are venous wall proteins, that play the major role in maintenance of an appropriate resilience and endurance of the venous wall [14-16]. Glycosaminoglycans constitute structure of intracellular matrix and thanks to interaction with the other components they influence on the venous wall properties. There are reports that present connections between smooth muscles and elastin fibers. These connections are significant for venous endurance when venous pressure is elevated. In varicose veins alterations of elastic fibers structure are present and they are separated from smooth muscle fibers [17]. A deficiency of type III collagen was observed in CVD patients [18].

Recent studies suggest that proteinases released by inflammatory infiltration cells, may be responsible for the venous wall hypertrophy. Inflammatory infiltration cells cause matrix metalloproteinase (MMP) activation and collagen dissolution in extracellular matrix. Moreover, activated endothelial cells release transforming growth factor- $\beta$ (TGF- $\beta$ ), which causes migration of muscularis cells and their proliferation in tunica intima [19]. The long-lasting secretion of TGF- $\beta$ induces MMP and tissue inhibitor of metalloprotease (TIMP) releasing [20]. The balance disorder between MMP and TIMP also seem to be important in extracellular matrix damage $[21,22]$. The other evidence suggest that altered hemodynamics and abnormal blood flow are main causes of the valvular damage [23]. Next research suggest that reflux in vessel lumen is caused by the valvule extension, atrophy of valve cusp and hemodynamic alterations $[24,25]$.

Recent studies has focused on the theory of the venous wall and valvular damage as the one of the major cause of the developmentof CVD, caused by chronic inflammatory process. Recent advances have shown that chronic inflammatory process and leukocytes - endothelial cells interactions are involved in vessel lumen dysfunctions, valvular incompetence, reflux, venous hypertension, varicose veins and ulcerations [26].

\section{Molecular mechanisms involved in the inflammatory process}

Recent advances in the understanding of CDV focused on interactions between leukocytes and vascular endothelial cells [27]. Attention has focused on the role of leukocytes in the pathophysiology of changes of the venous wall structure. The intense leukocytes infiltration, mainly macrophages and lymphocytes in CVD patients was observed [28]. The amounts of granulocytes, monocytes, macrophages and T lymphocytes increased in the venous wall of veins with the elevation of the blood pressure [29]. B lymphocytes also were present [30].

Chronic elevation of the blood flow through the venous pressure and shear stress alterations, may cause endothelial cell and leukocytes activation [3133]. Investigation of the leukocytes shows that the most activated leukocytes are isolated from patients with venous hypertension [34]. Activation of endothelial cells may be caused by their mechanical extension and that is linked with pathological blood flow and shear stress alterations [35]. It is clear that and shear stress is the major factor which affects endothelial cell functions [36].

The molecular mechanism of leukocytes adhesion to endothelial cells involves two stages. The first stage is called "I type activation", and it appears quickly. The activation consequentions are: endothelial cells constriction, selectin expression and von Willebrand factor (vWf) releasing. The second stage is called "II type activation", and involves adhesion molecules, cytokines and tissue factor [37-39].

The process of leukocytes extravasation can be divided into four steps: rolling, activation, adhesion and transendothelial migration [40] (Fig. 1). Extravasation of lymphocytes involves interaction of celladhesion molecules, their activation and chemokines activity [41-43].

During rolling leukocytes attach loosely to the endothelium by a L-selectins and E-selectins, which tether leukocytes to the endothelial cells [44]. Leukocytes tumbles end-over-end along the endothelium. Subsequently leukocytes are activated by various chemoattractants e.g.: interleukin 8 (IL-8), complement split products, macrophage inflammatory protein (MP$1 \beta$ ) and $\mathrm{N}$-formyl peptides. Moreover, hypertension is the cause of red blood cells (RBCs) extravasation, which degradation products are potent chemoattractants and presumably represent the initial signal for leukocytes. Also hypoxia leads to increased production of platelet activating factor (PAF), which activate leukocytes $[44,45,46,47]$. Binding of these chemoattractants with leukocytes surface receptors is an activating signal. In the next step, shedding of adhesion molecules from leukocytes surfaces occurs as a result of proteolytic enzymes action and they circulate as a soluble molecule in plasma [48]. Several studies have shown that plasma levels of soluble L-selectin increased in CVD patients [29]. Plasma levels of the adhesion molecules (ICAM1), endothelial leukocytes adhesion molecule (ECAM1), vascular cells adhesion molecule (VCAM-1) were higher in CVD patients than controls [49]. The acti- 


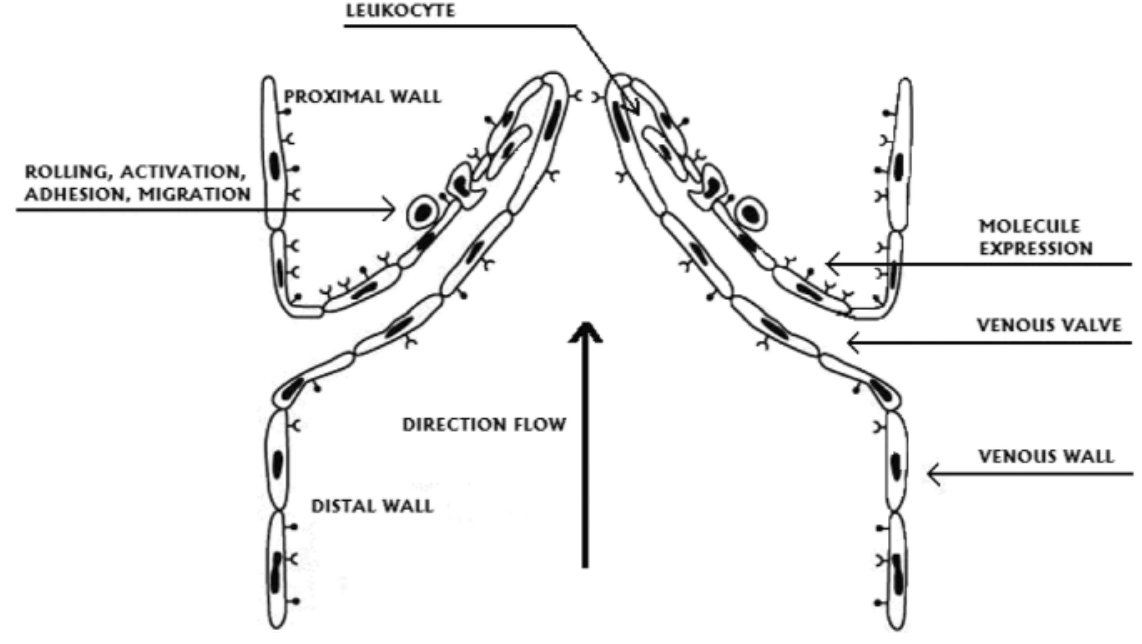

Fig. 1. Leukocyte- endothelial interactions on a venous valve [27]. vating signal induces a conformational changes in the integrin molecules. Increasing of the integrin molecule affinity for Ig-superfamily adhesion molecules on the endothelium occurs. The interaction between integrins and Ig-superfamily adhesion molecules provides firm adhesion of leukocytes to the endothelial cells. Leukocytes firm adhesion triggers their migration through the endothelium [50].

Numerous works have shown the leukocytes sequestration in valve cups and in the venous wall in CVD patients compared with controls [21]. Several studies confirm the "white cell trapping" hypothesis and massive leukocytes activation in the microcirculation followed by their migration to subcutaneous tissue [51]. This phenomenon is responsible for production and releasing of cytotoxic substances which lead to skin ulceration and also valve cups and the venous wall destruction [52-55]. Leukocytes produce, accumulate and release: histamine, tryptase, prostaglandins, leukotriens and cytokines. Histamine increases endothelial permeability and proliferation of smooth muscle cells. The evaluation of the amount and localization of infiltrative cells, shows that they are the most numerous in the proximal venous wall and in the valve cups [56].

Activated leukocytes migrate through proximal parts of endothelial cups and venous wall and cause the supporting elements destruction and valvular reconstruction, which may cause the valvular incompetence. Leukocytes through penetration to the skin and subcutaneous tissue may also trigger trophic changes and ulcerations [57].

\section{Summary}

Recent studies have shown that the inflammatory process plays a significant role in CVD pathophysiology. Reconstructions of the venous wall and venous valves, associated with their dilatation and relaxation, are the basic mechanism of the development of CVD and it is associated with the inflammatory process on their surface. Leukocytes activated during the inflammatory process release proteolytic enzymes, free radicals and cytokines which are responsible for the changes of the venous wall and venous valve, and also the development of tissue destruction and skin changes [58]. Moreover, inflammatory process in CVD patients secondarily leads to valvular incompetence, reflux and venous hypertension which further promote development of inflammatory reaction. Detailed understanding of these phenomenon may help with early CVD treatment, that aim is to inhibit inflammatory process. That may prevent complications of CVD development.

\section{References}

[ 1] Callejas JM, Manasanch J. Epidemiology of chronic venous insufficiency of the lower limbs in the primary care setting. Int Angiol. 2004;2:154-16.

[2] Ziaja K, Drazkiewicz T. Przewlekła niewydolność żylna. Przeg Flebo. 1993;1:7-14.

[3] Beaglehole R. Epidemiology of varicose veins. World J Surg. 1986;10:898-902.

[4] Callam WA, West A. Epidemiology of varicose veins. $\mathrm{Br} J$ Surg. 1994;81:167-173.

[5] Eklöf B, Rutherford RB, Bergan JJ et al. Revision of the CEAP classification for chronic venous disorders: consensus statement. J Vasc Surg. 2004;40:1248-1252.

[ 6] Kistner RL, Eklof B, Masuda M. Diagnosis of chronic venous disease of the lower extremitis: the CEAP classification. Mayo Clin Proc. 1996;71:338-345.

[ 7] Ono T, Bergan JJ, Schmid-Schönbein GN, Takase S. Monocyte infiltration into venous valves. J Vasc Surg. 1998; 27:158-166.

[8] Arnoldi CC. Venous pressure in patients with valvular incompetence of the veins of the lower limb. Acta Chir Scand. 1966;132:427-430. 
[9] Mashiah A, Rose SS, Hod I. The scanning electron microscope in the pathology of varicose veins. J Med Sci. 1991;27:202-206.

[10] Kowaleski R, Głowiński S, Sobolewski K, Wolańska M, Płoński A. Przebudowa macierzy międzykomórkowej w ścianie żylaków. Pol Przegl Chir. 2000;72:912-920.

[11] Travers JP, Brookes CS, Evans J et al. Assessment of wall structure and composition of varicose vein with reference to collagen, elastin and smooth muscle content. Eur J Vasc Endovasc Surg. 1996,11:230-237.

[12] Kockx MM, Knaapen MW, Bortier HE, Cromheeke KM, Boutherin-Falson O, Finet M. Vascular remodeling in varicose veins. Angiology. $1998 ; 49: 871-877$.

[13] Porto LC, da Silveira PR, de Carvalho JJ, Panico MD. Connective tissue accumulation in the muscle layer in normal and varicose saphenous veins. Angiology. 1995;46:243-249.

[14] Svejcar J, Prerovsky I, Linhart J, Kruml J, Beckova B. Content of collagen, elastin, and hexosamine in primary varicose veins. Clin Sci. 1963;24:325-330.

[15] Jacob MP, Badier-Commander C, Fontaine V, Benazzoug Y, Feldman L, Michel JB. Extracellular matrix remodeling in the vascular wall. Pathol Biol. 2001;49:326-332.

[16] Porto LC, Azizi MA, Pelajo-Machado M, Matos da SP, Lenzi HL. Elastic fibers in saphenous varicose veins. Angiology. 2002;53:131-140.

[17] Woodside KJ, Hu M, Burke A et al. Morphologic characteristics of varicose veins: possible role of metalloproteinases. $J$ Vasc Surg. 2003;38:162-169.

[18] Sansilvestri-Morel P, Rupin A, Jaisson S. Synthesis of collagen is dysregulated in cultured fibroblasts derived from skin of subjects with varicose veins as it is in venous smooth muscle cells. Circulation. 2002;106:479-483.

[19] Nicolaides AN. Patofizjologia przewlekłej niewydolności żylnej. Farm Pol. 2006;62:535-540.

[20] Nicolaides AN. Chronic venous disease and the leukocyteendothelium interaction: from symptoms to ulceration. Angiology. 2005;56:S11-S19.

[21] Badier-Commander C, Verbeuren T, Lebard et al. Increased TIM/MMP ratio in varicose veins: a possible explanation for extracellular matrix accumulation. J Pathol. 2000;105-112.

[22] Meissner MH, Gloviczki P, Bergan J et al. Primary chronic disorders. J Vasc Surg. 2007;46:54S-67S.

[23] Eger SA, Casper SL. Etiology of varicose veins from an anatomic aspect based on dissections of 38 adult cadavers. JAMA 1943;123:148-149.

[24] Labropoulos N, Giannoukas AD, Delis K et al. Where does venous reflux start? J Vasc Surg. 1997;26:736-742.

[25] Mastej K, Gacka M, Adamiec R. Usefulness of evaluation endothelial marker sof immuno-inflammatory activity In prognosis venous leg ulcer. Prz Flebol. 2005;13:3-7.

[26] Stvrtinova V, Jahnova E, Weissova S, Horvathova M, Ferencik M. Inflammatory mechanisms involving neutrophils in chronic venous insufficiency of lower limbs. Bratisl Lek Listy. 2001;102:235-239.

[27] Bergan J, Molecular Mechanisms in Chronic Venous Insufficiency. Ann Vasc Surg. 2007;21:260-266

[28] Coleridge Smith PD. Neutrophil activation and Mediators of inflammation in chronic venous insufficiency. J Vasc Res. 1999;36:24-36.

[29] Pascarella L, Schmid Schonbein GW, Bergan JJ. Microcirculation and venous ulcers: a review. Ann Vasc Surg. 2005; 19:921-927.

[30] Ciecierski M, Grzela T, Jawień A. Chronic venous insufficiency. Ter i Leki. 2002;1:5-10

[31] Takase S, Bergan JJ, Schmid-Schönbein G.W. Expression of adhesion molecules and cytokines on saphenous veins in chronic venous insufficiency. Ann Vasc Surg. 2000;14:427-435.
[32] Dormandy JA. Influence of blood cells and blood flow on venous endothelium. Int. Angiol. 1996;15:119-123.

[33] Gohel MS, Windhaber RAJ, Tarlton JFT, Whyman MR, Poskitt KR. The relationship between cytokine concentrations and wound healing in chronic venous ulceration. J Vasc Surg 2008;48:1272-1277.

[34] Coleridge Smith PD. Update on chronic-venous-insufficiencyinduced inflammatory processes. Angiology. 2001;52: S35-S42.

[35] Takase S, Delano FA, Lenrod L, Bergan JJ, Schmid-Schonbein GW. Inflammation in chronic venous insufficiency: is the problem insurmountable? J Vasc Res. 1999;36:3-10.

[36] Davies MG, Hagen PO. The vascular endothelium. Ann Surg. 1993;218:593-609.

[37] Coleridge Smith PD, Thomas P, Scurr JH, Dormandy JA. Causes of venousulceration: a new hypothesis. $\mathrm{Br}$ Med $J$. 1988;296:1693-1695.

[38] Lewis JC, Bennet-Cain AL, De Mars CS et al. Procoagulant activity after exposure of monocyte-derived macrophages to minimally oxidized low density lipoprotein. Co-localization of tissue factor antigen and nascent fibrin fiberat the cell suface. Am J. Pathol. 1995;147:1029-1040.

[39] Mangiafico RA, Malatino LS, Santonocito M, Spada RS, Benedetto FA. Plasma endothelin-1 release in normal and varicose saphenous veins. Angiology. 1997;48:769-774.

[40] Boisseau MR. Leukocyte involvement in the signs and symptoms of chronic venous disease. Perspectives for therapy. Clin Hemorheol Microcirc. 2007;37:277-290.

[41] Michiels C, Bouaziz N, Remacle J. Role of the endothelium and blood stasis in the appearance of varicose veins. Int Angiol. 2002;21:1-8.

[42] Michiels C, Bouaziz N, Remacle J. Role of the endothelium and blood stasis in the appearance of varicose veins. Int Angiol. 2002;21:18-25.

[43] Kirch D, Dienes HP, Kuchle R et al. Changes in the extracellular matrix of the vien wall- the cause of primary varicosis? Vasa. 2000;29:173-177.

[44] Saharay M, Shields DA, Porter JB, Scurr JH, Coleridge Smith D. Leukocyte activity in the microcirculation of the leg in patients with chronic venous disease. J Vasc Surg. 1997;25:265-273.

[45] Somers P, Knaapen M. The histopathology of varicose vein disease. Angiology. 2006;57:546-555.

[46] Wali MA, Eid RA. Changes of elastic and collagen fibres in varicose veins. Int. Angiol. 2002;21:337-343.

[47] Raffetto JD, Ross RL, Khalil RA. Matrix metalloproteinase 2 -induced venous dilation via hyperpolarization and activation of $\mathrm{K}+$ channale: Relevance to varicose vein formation. $J$ Vas Surg. 2007;45:373-380.

[48] Khan AA, Eid RA, Hamid A. Structural changes in the tunica intima of varicose veins: a hisstopathological and ultrastructural study. Pathology. 2000;32:253-257.

[49] Master K, Gacka M, Adamiec R. Usefulness of evaluation endothelial marker sof immuno-inflammatory activity In prognosis venous leg ulcer. Prz Flebol. 2005;13:3-7.

[50] Coleridge Smith PD. Deleterious effects of white cells in the course of skin damage in CVI. Int Angiol. 2002;21:26-32.

[51] Schmid Schonbein GW, Takase S, Bergan JJ. New advances in the understanding of the pathophysiology of chronic venous insufficiency. Angiology. 2001;52:S27-S34.

[52] Żmudzińska M, Czarnecka-Operacz M. Chronic venous insufficiency-an update. Part I-pathomechanism, sinus, diagnostics. Post Derm Alergol. 2005;2:65-69.

[53] Corcos L, De Anna D, Dini M. Proximal long saphenous vein valves in primary venous insufficiency. $J$ Mal Vasc. 2000;25:27-36.

[54] Takase S, Schmid Schönbein GW, Bergan JJ. Leukocyte activation in patients with venous insufficiency. J Vasc Surg. 1999;30:148-156. 
[55] Haviarová Z, Weismann P, Pavlíková D, Durdík S, Kovác P, Stvrtinová V, Mráz P. Mast cell infiltration in the wall of varicose veins. Acta Histochem. 2002;104:357-360.

[56] Yamada T, Tomita S, Mori M, Sasatomi E, Suenaga E, Itoh T. Surgery Increased mast cell infiltration in varicose veins of the lower limbs: a possible role in the development of varices. Surgery. 1996;119:494-497.

[57] Gandhi RH, Irizarry E, Nackman GB, Halpern VJ, Mulcare $\mathrm{RJ}$, Tilson MD. Analysis of connective tissue matrix and pro- teolytic activity of primary varicose veins. J Vasc Surg. 1993; 18:814-820.

[58] Ramelet AA. Clinical benefits of daflon 500mg in the most severe stages of chronic venous insufficiency. Angiology. 2001;52:S49-S56

Submitted:12 February, 2009 Accepted after reviews: 19 April, 2009 